\title{
Frihet under tvang
}

\author{
Stein M. Wivestad \\ NLA Høgskolen, Norge
}

\section{SAMMENDRAG}

Dette bokessayet samtaler med Lars Løvlies bok Politisering og pedagogisk motstand: Veien til en barneorientert praksis (2021). Boken er relevant for alle som har valgt oppgaven med å oppdra og undervise barn, eller som forbereder seg til denne oppgaven. Boken er et humaniora-studium i essayform som konkretiserer hvordan pedagogisk forskning er og bør være noe mer enn forskning med naturvitenskap som forbilde. Den er et kall til å våge å gjøre motstand mot administrative krav som forstår oppdragelse og undervisning som en form for produksjon. Den inviterer til å stille grunnleggende spørsmål som vi ikke blir ferdige med å samtale om. Den oppfordrer til å velge forskningsprosjekter der det å lytte til barnas stemme og det å leve i relasjon med barna blir undersøkt nærmere. Boken kan fremme pedagogisk visdom og kjærlighet. Kan visdom og kjærlighet være ledestjerner når vi søker etter veien til en barneorientert praksis, en praksis som fremmer barnas frihet under nødvendig tvang?

Nøkkelord: kontroll; Lars Løvlie; moralsk visdom; omvending; praksis og produksjon

Mottatt: Mars, 2021; Antatt: Mai, 2021; Publisert: September, 2021

\section{ABSTRACT \\ Freedom under constraint}

The essay "Freedom under constraint" converses with a book by Lars Lovlie from 2021 about recent educational politics in Norway. He documents the resistance against it from educators and opens a search for the way to a child-oriented practice. The book is relevant for all who have chosen the task of upbringing and teaching of children or are preparing themselves for this task. The book fleshes out an educational study based in the humanities. It is a call to dare to resist administrative demands rooted in an understanding of education as a kind of production. It invites to ask foundational questions, about which we cannot finish our conversation. It encourages to choose research projects where listening to the voice of children and living in relation with them are investigated more closely. The book may forward educational wisdom and love. Can wisdom and love be guiding stars when we search for the way to a child-oriented practice, which cultivates the freedom of the children under necessary constraint?

Keywords: control; Lars Lovlie; moral wisdom; personal transformation; practice and production

Korrespondanse: Stein M.Wivestad, e-post: Stein.Wivestad@NLA.no

(C) 2021 Stein M. Wivestad. This is an Open Access article distributed under the terms of the Creative Commons Attribution 4.0 International License (https://creativecommons.org/licenses/by-nc/4.0/), allowing third parties to copy and redistribute the material in any medium or format and to remix, transform, and build upon the material for any purpose, even commercially, provided the original work is properly cited and states its license.

Citation: Stein M. Wivestad. «Frihet under tvang» Nordisk tidsskrift for pedagogikk og kritikk, Vol. 7, 2021, pp. 303-314. 


\section{S. M. Wivestad}

\section{$\AA$ følge veien og vare på sporet}

Den som søker å begrunne pedagogisk handling trenger 'metode' i ordets opprinnelige betydning (meta hodos = etter veien), en trenger å følge en vei eller søke et spor (Tranøy, 1960, s. 150; Wyller, 1960, s. 146). Veiens eller sporets utgangspunkt, ideelle egenskaper og mål er det uenighet om. Forskning med naturvitenskap som forbilde legger vekt på å beskrive veien så nøyaktig som mulig, slik at forskerens eventuelle funn kan bekreftes av andre. Forskning med humaniora (det "mer menneskelige») som forbilde er opptatt av å fremme gode forskerholdninger (mot, ydmykhet, åpenhet, ærlighet og grundighet), slik at forskeren følger spor som kan lede til noe som er verdifullt, unikt og annerledes enn det som har vært tenkt og gjort tidligere. Alle forskere bør søke sannhet. Vi bør gjøre oss selv maksimalt åpne for at andre kan vurdere kritisk den veien og de sporene som vi har fulgt. Uansett hvilke metodeidealer og forskningsmål vi følger, bør vi våge å sette våre egne fordommer på spill. Ifølge Løvlie bør lærere (og oppdragere generelt) søke etter veien til en barneorientert pedagogisk praksis. Hvordan kan vi være på sporet etter en barneorientert praksis? Hva slags begrensninger av barnas frihet kommer vi ikke utenom når vi oppdrar og underviser, og hvordan kan vi samtidig ivareta deres frihet?

Politikere både på venstresiden og høyresiden har siden 1990-årene ledet skolen ut fra tanker om kompetanse, konkurranse og kontroll. Veien til pedagogisk praksis har blitt dominert av naturvitenskapelig inspirert pedagogisk forskning, administrative krav basert i produksjonstenkning og teknologi innført utenfra. Løvlie inviterer oppdragere og lærere til å gjøre motstand mot denne politiserte veien, fordi den mangler god pedagogisk begrunnelse. For å vurdere alternativer har han vært spesielt opptatt av den filosofiske samtalen med Francke, Rousseau, Kant, von Humboldt og Habermas. Jeg vil prøve å vise at også Aristoteles, Comenius, Kierkegaard, Buber, Bollnow og Kristvik bør være med i samtalen. De representerer tradisjoner som orienterer seg ut fra andre forutsetninger enn de som har dominert «vår tradisjon» siden opplysningstiden (Wivestad, 1998, 2013).

\section{Ydmykhet og åpenhet}

Lars Løvlie, f. 1938, har helt fra 1970-årene vært en markert stemme innen allmenn pedagogikk både i norsk, nordisk og engelskspråklig sammenheng. I tilknytning til spenningen mellom naturvitenskapelig inspirert og humaniorainspirert forskning kan det nevnes at han opprettet forskergruppen Humaniora-studier $i$ pedagogikk ved Universitetet i Oslo. Han har et skarpt blikk for hva som kan true barnas beste, og lar konkrete eksempler belyse en større pedagogisk og didaktisk sammenheng. Kort sagt handler boken om spenningen mellom frihet og tvang.

Boken er skrevet i essayform. Det inviterer leseren til å samtale med forfatteren og prøve å følge noen av de samme sporene som forfatteren har fulgt, samt å vurdere kritisk hans premisser og konklusjoner og lære av ham. En anmeldelse av boken hevder at den inneholder "et forslag til hvordan man kan løse 'oppdragelsens paradoks'» 
(Torjussen, 2021, s. 38). Det er riktig at Løvlie reiser spørsmålet om «samtalen kan fri oss fra det pedagogiske paradoks», men han sier samtidig: «Kanskje ikke» (Løvlie, 2021, s. 101). Slik jeg tolker boken, fremstilles spenningen mellom frihet og tvang ikke som et problem som kan løses, men som en kontinuerlig utfordring for oppdragerne.

Boken avsluttes med Franz Kafkas fortelling om en person som ønsker å bli «kallet til tjeneste» (Løvlie, 2021, s. 139). Han settes på prøve gjennom spørsmål som han ikke forstår. Men nettopp ved å innrømme at han ikke forstår spørsmålene, består han prøven. Jeg oppfatter dette som en tolkningsnøkkel til boken som helhet. Åpenhet for det som vi ikke forstår, undringens gave, "kan løfte oss dit gåte holder gåte i sin hånd» (s. 129). Noen spørsmål blir vi aldri ferdig med å samtale om. Det gjelder overordnede mål og handlingsvalg i den enkelte unike situasjon, og det gjelder begrunnelsene for målene og valgene våre. Grunnlaget for begrunnelsene er vår forståelse av den helheten som vi selv bare er en liten del av. Hva er meningen med at jeg er til? Små barn er åpne for det «uutsigelige» (s. 130), åpne for å holdes oppe uten å ha kontroll. Ydmykhet og åpenhet står i fare dersom hovedsaken blir sikring og kontroll.

\section{Konkurranse, kontroll og motstand}

Essayet om «den uekte lodning» handler om to deler som egentlig skulle henge godt sammen, to systemer som burde være «loddet sammen» på en ekte måte: administrative krav og konkret pedagogisk praksis i skolen. I løpet av de siste 30 årene har denne sammenhengen blitt svekket gjennom «en konflikt mellom to kulturer, mellom en styringsideologi og en pedagogisk kultur»(s. 31). I 1987 hadde vi i Norge en skole preget av «en solidarisk samværskultur» (s. 37), med en læreplan som la vekt på «nasjonale verdier og lokale læreplaner»(s. 33). I 1990-årene la politikerne ned Grunnskolerådet og Rådet for videregående opplæring - organer som hadde med mange personer med nær kontakt til pedagogisk praksis. De ble erstattet med jurister, økonomer og organisasjonsteoretikere, og det ble innført detaljerte nasjonale læreplaner med «mål- og resultatstyring» etter «modeller fra produksjonslivet» (s. 14). Politiseringen av skolen hadde utgangspunkt i et ønske om «konkurranse, effektivisering og markedstilpassing» (s. 18). Det ble lagt vekt på «målstyring og dokumentasjon» og det ble innført "pakketilbud for disiplinering og atferdskontroll» (s. 22) med programmer fra USA (s. 45).

Dette har møtt motstand fra lærere, foreldre og noen fagpedagoger. De har opplevd bestemte administrative krav og føringer som en feilaktig form for tvang - av både voksne og barn - en dårlig begrunnet tvang som har svekket den pedagogiske kulturen og den solidariske samværskulturen i skolen. Et spørsmål oppdragere stadig må stille seg er dette: "Hvordan dyrker jeg friheten der det er tvang?» (s. 21), eller slik Kant antakelig formulerte det: "Wie kultivire ich die Freyheit bei dem Zwange?» (Kant, 1803, s. 27). Uttrykket «bei dem Zwange» kan oversettes med "under den tvangen" som vi ikke kommer utenom når vi oppdrar og underviser. Spørsmålet henger sammen med at det nødvendigvis er et asymmetrisk forhold mellom barn og 


\section{S. M. Wivestad}

voksne (Løvlie, 2021, s. 101). I denne relasjonen, der oppdrageren må gi føringer og sette grenser, må strukturere tid og rom, må velge ut noe og velge bort noe annet der vil Kant at oppdrageren skal fremme en reell frihet for barna, ikke bare gi dem «en følelse av frihet», slik Herner Sæverot (2017, s. 117) har omtolket Kants spørsmål. Kants spørsmål er en apori, et uføre uten utvei, en situasjon som oppdragere må stå i. Hvordan kan de det?

\section{$\AA$ Aytte till barnets stemme}

For å klargjøre historisk hvordan den pedagogiske aporien har blitt møtt i praksis, har Løvlie skrevet to lengre essay: ett om «det indre liv» i pietistisk oppdragelse (August Hermann Franckes pedagogikk) og ett om «det uferdiges pedagogikk» (Jean-Jacques Rousseau som oppdrager). Begge disse ønsket å fremme barnas «indre liv» (s. 22 og 23). Handlinger skulle styres av personen selv, subjektet. Men begge la opp til en pedagogisk praksis som ødela intensjonen. Grunnen var, ifølge Løvlie, at deres pedagogikk åpnet for at de voksne kunne la vere å lytte til barnets egen stemme. De voksne var sikre på at de selv visste hva som var "til barnets beste» (s. 101). Samme feil finner Løvlie igjen når undervisning og læring forstås som en form for produksjon: «Et perfekt produksjonssystem krever topp produktkontroll» (s. 124-125). Politikere og teknokrater tror at «læringstrykk» (s. 124), «målstyring, markedsorientering, konkurranse og belønningssystemer» (s. 41) med basis i «evidensbasert forskning» (s. 136) kan sikre en god skole.

Manglende innsikt i egen begrensning og mangel på ydmykhet er en gjennomgående fristelse for mennesker. Kong Kreon, i skuespillet Antigone, tror at han selv har sikker kunnskap (episteme) om hva som bør gjøres, og han har også makt til å tvinge igjennom det han mener bør gjøres. Han vil ikke lytte verken til sin sønn eller til andre, vil ikke overveie alternativer og vil ikke ta hensyn til religiøse tradisjoner. Spillet ender tragisk med at de fleste i kongens familie dør. Sluttordet formulerer en alternativ vei: «Den vissaste vegen til lykke på jord / er visdom (phronesis) og age for gudgjeven lov» (Sofokles, 441 f. Kr./1964, s. 260). Kan en vitenskapsfilosofi som ensidig vektlegger epistemologi og metodisk sikret kunnskap være en sikker vei til barnas beste? Sofokles og senere Aristoteles hevder at det trengs visdom (phronesis) som kan sette detaljerte kunnskaper og ferdigheter inn i en større sammenheng. Da må en knytte bånd til gode og kloke personer, tilegne seg de moralske dygdene, venne seg til å tenke klart og langsiktig når en selv overveier handlingsalternativer og være åpen for å bli korrigert av andre. Løvlie understreker også betydningen av samtale. Vi trenger åpenhet for å «ta den andres stemme inn» (Løvlie, 2021, s. 126-127). Han ønsker en pedagogisk forskning som har utgangpunkt i dagligspråket og i praktikernes konkrete erfaringer. Det kan skje på mange måter, også via kunst. Skjønnlitteratur kan hjelpe læreren til å få "selvinnsikt som person» (s. 136). Det kan også studier av film bidra til. Som et eksempel vil jeg nevne en masteroppgave som drøfter hvordan en film om temming av hester kan inspirere oppdragere og bidra til at de får bedre 
innsikt (Aasheim, 2015). Pedagogisk interessante filmer som "venter på» at noen skal skrive om dem er bl.a. A vare og ha (Philibert, 2002), Tokyo godfathers (Kon, 2003), Klassen (Cantet, 2008), Gutten med sykkelen (Dardenne \& Dardenne, 2011) og Barndom (Olin, 2017).

\section{Autoritar tvang i pietistisk tradisjon}

Det var noen fariseere som følte seg sikre på å handle rett ved å følge de over 600 detaljerte forskriftene i Moseloven. Jesus anklaget dem for hykleri. Pietistene reagerte mot rettroende lutheranere som ikke levde etter det de lærte. Slike erfaringer er oppsummert i en liturgisk bønn som har vært brukt i vår tradisjon siden 1528, og som fortsatt er med i én av de fire formulerte forbønnene som kan brukes i høymessen: «Vern oss mot vrang lære og død tro» (Kirkerådet, 2020, s. 101; NoS, 2013, nr. 980.1). Selv om August Hermann Franckes pietistiske pedagogikk «ikke var dominert av myten om syndefallet» (Løvlie, 2021, s. 58), brukte noen av pietistene, i tråd med «den folkelige tradisjon» i deres samtid (s. 61), voldelige midler for å «bryte barnets egenvilje» (s. 65). Dette var opplagt uklokt, da en ikke tok hensyn til at barnets vilje blir styrt av følelser. De glemte å følge formaningen fra Paulus: «Dere foreldre, vekk ikke sinne og trass hos barna deres, men gi dem omsorg, så de får en oppdragelse og rettledning som er etter Herrens vilje» (Ef 6,4). I kristen tradisjon er nestekjærlighet en grunnverdi. I humanistisk og kristen tradisjon må kjærligheten praktiseres med visdom (phronesis).

Løvlie er ikke den første som har sammenliknet Francke og Rousseau. Ved begynnelsen av andre verdenskrig skrev Erling Kristvik en artikkel som diskuterer hvilket begrep for pedagogisk virksomhet som kan gi pedagogisk ansvarlige mennesker det beste utgangspunktet «i striden for eigen framtidslagnad» (Kristvik, 1940, s. 295). Han avviser både autoritær «innprenting» og ensidig «utfalding» av barnets indre krefter, og forsøker å oppheve spenningen mellom kristenhumanistisk og naturalistisk tradisjon ved å velge «innplanting» som grunnbegrep. Begrepet søker å ta vare på det beste både i barnet, i kulturen, og i det som er høyere enn både barnet og kulturen.

Uboteleg skade har pietismen valda med å spreia mistillit til desse Gud-gjevne krefter i barnet og med framleies å setja innprentinga i høgsætet. [...] frigjering er aldri valdsferd. Gud bur ikkje i stormen og ikkje i jordskjelven og ikkje i elden, men i den stille susinga, $i$ «kjærlighetens gjenskapermakt», ikkje $i$ ein pedagogikk fylt av mistillit til barnet og væpna med tuktemiddel, men i ein oppsedarkunst som let liv ovanfrå eina seg med liv nedanfrå. (s. 314-315)

Her er det implisitt referanse til profeten Elia (1 Kong 19, 11-13) og til den «skjøre stillheten» (vers 13) som fikk Øyvind til å stanse opp og innse det meningsløse ved å lese og studere bare for å bli bedre enn de andre i klassen. Bård skolemesters undervisning og personlige historie formidlet «kjærlighetens gjenskaper-makt». Øyvind møtte motstand, og fikk hjelp til å sette seg nye mål i livet ut fra «den uendelige 


\section{S. M. Wivestad}

kjærlighetens ild, som bærer frem når man møter menneskers uventede godhet» (Bjørnson, 1860/1955, s. 23 og 44-45).

Løvlie er klar over sammenhengen mellom Jan Amos Comenius, herrnhuterne og haugianerne (s. 68-69), men har ikke tatt med at Comenius hadde et syn på barna som tydelig avvek fra pietisten Francke. Over hundre år før Rousseaus Emile utformet Comenius prinsipper for oppdragelsen av småbarn som viser at han slett ikke var «tonedøv overfor barns indre» (s. 67). Comenius holdt barna fram som forbilder for de voksne når det gjaldt ydmykhet og fredelig sinnelag. Derfor formante han foreldrene til å se opp til barna som sine «læremeistrar». Han var opptatt av at barna måtte få leke og glede seg: Foreldre må «syte for at borni deira aldri må li naud på glede og gaman» (Comenius, 1966, s. 17 og 31). Et tankevekkende spørsmål som Løvlie knytter til Rousseau, kan etter min mening også knyttes til Comenius: «Kanskje den beste lærer er han som har et nært forhold til barnet i seg selv?» (Løvlie, 2021, s. 136). Ydmykhet er en dygd som åpner for å gjøre eksistensielle, religiøse erfaringer.

\section{$\AA ̊$ bli «holdt av noe annet enn seg selv»}

Løvlie har valgt å lytte til kilder som fremstiller religiøse erfaringer. Nærmest kommer han slike erfaringer der det er tale om «en eksistensiell opplevelse av Guds nærvær» i fellesskap med andre (s. 71). Jeg oppfatter eksistensielt skjellsettende erfaringer som en omvending "som skjer med bevisstheten når den erkjenner seg selv i det fremmede og andre» (Gadamer, 1986/2010, s. 396). Det er imidlertid lite som taler for at religiøs omvending skjer "fra egen tenkning til tro», slik Løvlie (2021, s. 72) hevder, selv om refleksjoner kan ha en forberedende funksjon. En «reflekterer sig ikke ind i det at være Christen, men ud af Andet for at blive Christen" (Kierkegaard, 1859/2012, s. 72). Utgangspunktet for å gjøre religiøse erfaringer er gjerne en opplevelse av tomhet og uro i det endelige, begrensede og trivielle. Det åpner for ærefrykt overfor noe som oppleves som uendelig sant og skjønt (Kristjánsson, 2016, s. 709). Sofokles kalte det «age for gudgjeven lov». Det kommer til uttrykk i Augustins bønn: «Du har skapt oss til deg, og vårt hjerte er urolig inntil det finner hvile i deg» (Augustinus, 1996, s. 3) og i Kierkegaards tanke om at ubetinget kjærlighet bare kan komme til oss som er en ufortjent gave, en gave som vi bør gi videre uten å ta ære selv: «Any teacher who is master so that she may become less than the master [...] is working on behalf of a gift that she knows is not hers to give» (Tubbs, 2005, s. 404; Wivestad, 2011). Jeg er enig i at det intersubjektive, daglige «språket er den gave som løfter det subjektive til det allmenne og finner seg selv i det» (Løvlie, 2021, s. 130). Men den religiøse erfaringen er en erfaring av noe som er høyere også enn det menneskelige språket. "Allting holder og blir holdt av noe annet enn seg selv», står det i diktet av Stein Mehren, som Løvlie siterer (s. 129). Menneskets språk og historie er noe annet enn en selv, på den måten at språket og historien er noe en selv tilhører. Men Mehrens dikt kan også tolkes religiøst: «vår lengsel strekker seg etter evig liv» (Mehren, 1975, s. 84). 
Rousseau skiller mellom «selvkjærlighet» og «egenkjærlighet» og Løvlie tolker selvkjærligheten som barns naturlige driv «til å leve og å lære» (2021, s. 91-92). Jeg er enig i at vi bør ta vare på og styrke denne positive, livsbevarende selvkjærligheten hos barna, men det er samtidig viktig å spørre om vi kan unngå at egenkjærlighetens «fete nådeløse ego» (Murdoch, 1970, s. 52) får dominere. Rousseau var selv smertelig klar over problemet. Etter å ha forsømt plikten til å oppdra sine egne barn, skriver han følgende: "Den som ikke er i stand til å fylle sine plikter som far, har ingen rett til å bli det. [...] Tro meg lesere: For enhver som har et hjerte og forsømmer slike hellige plikter, kan jeg spå at han i lang tid vil felle bitre tårer over sitt feiltrinn og aldri vil finne trøst» (Rousseau, 1762/2010, s. 34).

Martin Buber hevder at mennesket har et todelt jeg: "Jeg-Du» er et annet jeg enn «Jeg-Det» (Buber, 1967, s. 6). Utfordringen for mennesket er å unngå at det andre jeget (Jeg-Det) blir overordnet, slik at en erfarer og bruker alt på sine egne premisser. Derfor må personen som helhet ha sin forankring i jeget som sier Du. Du-forholdet er en relasjon vi lever i «av nåde» (s. 12). Buber hevder at det som er avgjørende for å unngå at vi løsrives fra du-verdenen, det er jegets forhold til det evige Du, forholdet til den absolutte person, Gud. Vi trenger å holdes oppe av noe som er høyere enn alt menneskelig, vår egen tenkning inkludert. "Den som trer inn i det absolutte forhold, ham angår intet enkelt mer, [...] for det å tre inn i det rene forhold betyr ikke å se bort fra alt, men å se alt i Du'et» (s. 75-76). Begrunnelsen for at vi bør leve slik gir Buber gjennom «en ontologisk beskrivelse av hva som gjør mennesket til menneske» (Wivestad, 1993, s. 106).

Erling Kristviks drøfting av pedagogisk praksis kan ses i sammenheng med denne tenkningen: Oppdragelse forstått som «utfalding» fremmer «frigjeringa og utløysinga av den medfødde naturen" (Kristvik, 1940, s. 299). Både kunst og vitenskap kan bidra til det på en god måte. Men «kunst og vitskap kan ikkje vinna over dyret i mennesket. Tvert om, desse åndsverksemdene eggjar og stimulerer dyret, hissar det til nye tilsprang. Og når dei kjem, ramlar ei verd saman i blod» (s. 309). Dette var profetisk tale i 1940. Alternativet formulerer han slik: Dersom «Kristus tek bustad i hjarte og hug» da plantes det noe «frå ævelivet som ber ein straum av kjærleiksmakt inn i kalde sjølvopptekne, hatefulle menneskesjeler» (s. 314). En slik innplanting forutsetter omvending: et nei til det egenkjærlige jeget, et nei til å la jeget «som sier Jeg-Det» får dominere en selv.

\section{Omvending og selvdanning}

Løvlie hevder, med utgangspunkt i Habermas, at det er en «umulig fordring» $\mathrm{i}$ et krav om omvending, når det bare kan virke «ved at den omvendte har inderliggjort en fremmed vilje og selv utøver den tvang som er pålagt ham eller henne» (Løvlie, 2021, s. 63). Etter min mening blir denne påstanden feil dersom tvangen og det fremmede representerer noe som en selv erkjenner som sant og godt. Slik er det i Platons huleliknelse, der den frigjorte fangen trekkes «med makt [...] opp fra hulen» (Platon, 


\section{S. M. Wivestad}

2001, s. 270, bok 7, 515c) og etter hvert venner seg til å se alt i lyset fra det Gode. Slik er det i Hegels forståelse av danning. Danning innebærer å «erkjenne det egne i det fremmede» (Gadamer, 1986/2010, s. 40). Og slik er det også i Paulus’ omvending (Løvlie, 2021, s. 69). Det dramatiske møtet med den han forfulgte ble utgangspunktet for den vakre oppfordringen som han senere gir til menigheten i Filippi: «Ha samme sinnelag og samme kjærlighet, vær ett i sjel og sinn. Gjør ikke noe av selvhevdelse og tom ærgjerrighet, men vær ydmyke og sett de andre høyere enn dere selv. Tenk ikke bare på deres eget beste, men også på de andres. La samme sinnelag være i dere som også var i Kristus Jesus!» (Fil 2, 2-5). Den enkelte som lever i relasjonen med Kristus velger selv å si nei til selvhevdelse og å sette andre høyere enn seg selv. Jeget danner eller «bilder» seg selv med bildet av Kristus som forbilde.

\section{Pedagogikk som moralsk praksis og produksjon}

Løvlie legger vekt på sammenhengen mellom det subjektive (selvstendige jeget) og det intersubjektive, siden "det subjektive ikke først er personen, men relasjonen» (Løvlie, 2021, s. 25 og 107). Både innprenting og voldelig straff (hos noen pietister), skjult tilrettelegging av situasjonen (Rousseau) og moderne utdanning med kompetansemål, tester og systematisk forsterking av atferd som andre har definert som positiv - innebærer at barna tvinges eller manipuleres på måter som ikke ivaretar deres frihet. Både påvirkning (med håndverkeren som forbilde) og det å fremme vekst (med gartneren som forbilde) innebærer at oppdragelsen forstås som produksjon, der en prøver å få kontroll over prosess og resultat.

Begge oppfatninger er innen visse grenser meningsfylte [...] Men begge oppfatninger tar feil når det gjelder å forstå hva oppdragelse er. I oppdragelsen trer nemlig et fritt vesen et annet fritt vesen i møte med visse fordringer, og derfor må oppdrageren fra begynnelsen av prinsipielt ta den annens frihet med i betraktningen. Men å anerkjenne denne frihet betyr samtidig å si ja til oppdragelsen som et vågespill (ein Wagnis) [...]. (Bollnow, 1969, s. 148-149)

Hvis vi forstår oppdragelse og undervisning som produksjon (poiesis), dvs. teknisk virksomhet der målet bare er utenfor det vi gjør, da må vi, for å sikre at produktet får den ønskede kvalitet, søke å få mest mulig kontroll over veien frem til produktet. Faren er da at barnet ikke blir møtt som et fritt vesen. Tvangen blir autoritær på en åpen eller skjult måte. Ifølge Bollnow må oppdragere møte barnet med fordringer, de må ta kontroll over det de selv gjør og de rutiner og regler som de møter barna med, men de kontrollerer ikke situasjonen som helhet og resultatene. Når vi aktivt anerkjenner barnets frihet, da forstår vi oppdragelse og undervisning som et risikabelt vågestykke. Hva slags tvang kan være legitim, og hvordan bør den praktiseres?

Ifølge Aristoteles innebærer "den rette oppdragelse (paideia)» at barnet venner seg til å føle «glede og smerte ved de rette ting» (Aristoteles, 1999, 1104b13). Dette kan likne på et program for atferdskontroll, men denne formen for vanedanning 
forutsetter at oppdrageren er en legitim autoritet, en som er åpen for å bli korrigert når en gjør noe som ikke er holdbart. Aristoteles forstod oppdragelsen primært som en moralsk handling (praxis). Målet er ikke bare det gode en skal fram til (pro i produksjonen). Målet er også et gode som er bygget inn i det som oppdrageren gjør og er. Oppdrageren må derfor stadig vurdere om veien som følges er moralsk god ikke bare om den er effektiv. Det bør være sammenheng mellom lærerens method og lærerens personlige manner (Fenstermacher, 2001). Hver oppdragelseshandling bør uttrykke og konkretisere en vei opp fra det som er mangelfullt eller ondt og opp til det som er godt. Og hva som er godt og ondt må det stadig samtales om. Det kan bare tegnes skisser av det gode liv på forhånd - ikke produksjonstegninger. Skissene konkretiseres i den enkelte unike situasjonen. En må spørre: Hvilke begrensninger må barnet tåle i denne situasjonen? Hvordan bør jeg nå gi barnet frihet? Hvis barnet erfarer at oppdragerens handlinger er gode, kan det bidra til at barnet selv «føler glede og smerte ved de rette ting». Aristoteles tenkte at den rette oppdragelse forutsetter at barnet frivillig velger å følge gode forbilder; at barnet velger å se opp til, lytte til og etterlikne mennesker som er preget av moralsk visdom (phronesis).

Men oppdrageren må da være forberedt på at barnet velger annerledes enn en ønsker. Det kan oppleves som ydmykende nederlag. Her trenger Aristoteles et supplement. God praksis forutsetter ikke bare at den voksne er et godt forbilde, men også at det er en gjensidig kjærlighet mellom den voksne og barnet, en kjærlighet som knytter dem sammen på tross av forskjeller og ulike valg. En slik grunnleggende symmetri mellom oppdrager og barn øker sjansen for at barnet selv velger det som er ønskverdig. Når det gradvis blir mer «symmetri mellom partene» også i samtalen (Løvlie, 2021, s. 101), da er oppdragerens oppgave i ferd med å bli opphevet. Men så lenge barnet er i relasjonen til en oppdrager, vil det hele tiden være slik: "What is crucial in order for one's desires to be transformed into those of a virtuous person [...] is that one love and be loved by the moral exemplar set before one» (Herdt, 2008, s. 28).

En kombinasjon av kjærlighet og moralsk visdom synes å være en forutsetning for at nødvendig tvang skal være legitim. Kjærligheten åpner for oppfinnsomhet når det gjelder å se hva som er godt for den andre. Den kan hjelpe oppdrageren til å våge å være autoritet uten makt, våge å vise barna tillit og våge å være åpen, selv når en risikerer å bli latterliggjort. Den kan gi styrke til å bli stående i et fritt møte med vanskelige barn, i stedet for å trekke seg ut av relasjonen og styre gjennom straff og belønning. Kjærligheten viser en retning. Den moralske visdommen hjelper til med å finne passende tid, sted og måte for å gjøre det som vi egentlig ønsker å gjøre som oppdragere (Wivestad, 2008). For å unngå at dette blir abstrakt prat, trenger vi å bli inspirert og opplyst gjennom eksempler. Fortellingen om Marte Spurkeland og klassen hennes viser et slikt eksempel (Løvlie, 2021, s. 72-73 og 103-106). Det er ønskelig med pedagogisk forskning som går inn i samtale med og reflekterer over liknende konkrete fortellinger. 


\section{S. M. Wivestad}

\section{Veien til en barneorientert praksis}

Visdom og kjærlighet er gode ledestjerner, men en oppdrager trenger konkrete utgangspunkt i dagligspråket, "tradisjonen» og «kritisk teori» (Løvlie, 2021, s. 136) for å komme på sporet av en barneorientert praksis. Pedagogiske humaniora-studier knyttet til teologi, filosofi, historie, språkfag og kunstfag gir mulighet for kritisk drøfting av pedagogiske spørsmål, som vi stadig må innrømme at vi ikke kan svare på. Den som vil bli kallet til å tjene barnas beste, må arbeide med slike umulige spørsmål. Det er slik en kan bestå "prøven» (s. 140) som krever handling i situasjoner der en skal fremme frihet under nødvendig tvang - uten å ha en «oppskrift».

Løvlies bok slår "et slag for skjønnlitteraturen» (s. 136). En skjønnlitterær kilde, f.eks. «om forholdet mellom lærere og elever, barns behov, lærernes oppgaver og skolens mandat» (s. 49), kan danne utgangspunkt for pedagogisk forskning som både er relevant og mulig å gjennomføre på avgrenset tid. I slike drøftinger kan stemmene til en eller flere av de nevnte pedagogene og filosofene være med i samtalen. Løvlie drøfter bl.a. et eksempel fra Per Olov Enquists selvbiografi (s. 51-54) og fra Rousseaus bekjennelser (s. 75-76). Noen andre eksempler kan vise at det er mange muligheter: En beretning om relasjonen mellom en lærer og en gruppe gatebarn i revolusjonstidens Sveits (Pestalozzi, 1799/1970), en fortelling om relasjonen mellom en husmannsgutt og en skolemester (Bjørnson, 1860/1955), et oppgiør med en skole som la ensidig vekt på nyttige fakta (Dickens, 1854/1935), forsøk på å hjelpe hjemløse barn og småkriminelle ungdommer i Russland på 1920-tallet (Makarenko, 1925-1935/1977), et brev til en autoritær far (Kafka, 1953/1991), fortellinger fra en skole i New York som tok imot elever som var skadet av den offentlige skolen (Dennison, 1969/1999), en novelle om en lærer som lærte av en elev hvordan undervisningen kunne bli mer livsnær og levende (Nagibin, 1953/1979), en svensk lærers fortelling om betydningen av konkrete og meningsfylte arbeidsoppgaver (Sjöberg, 1979), en journalists sammenlikning av egne erfaringer fra amerikansk oppdragelse med den hun erfarte i noen jeger- og samlerkulturer (Doucleff, 2021).

Noen av disse eksemplene er pedagogiske klassikere. De kan åpne for å lete etter aktuelle eksempler i ny litteratur. En kritisk drøfting av slike eksempler gir oss ikke pedagogiske oppskrifter som sikrer gode resultater. Det er alltid mulig å handle feil. Eksemplene kan imidlertid gi nyanserte erfaringer knyttet til bestemt tid og sted og konkrete situasjoner. Slike erfaringer kan oppdrageren sammenlikne med de unike situasjonene som en selv står i og kommer i, når en stadig på nytt må spørre seg selv om hvordan en kan kultivere friheten under tvangen.

\section{Takk}

I arbeidet med artikkelen er det flere som har gitt meg gode innspill: Jostein Litlere, Jostein Sæther, Tone Sævi, Turid Løyte Harbo og fagfellene i NTPK. Hjertelig takk! 


\section{Referanser}

Aristoteles. (1999). Den nikomakiske etikk (Ø. Rabbås \& A. Stigen, Overs.). Bokklubben Dagens Bøker.

Augustinus, A. (1996). Bekjennelser (O. Hjelde, Overs.). Thorleif Dahls kulturbibliotek.

Biørnson, B. (1955). En glad gutt En glad gutt, Brudeslåtten, Blakken, Trond (s. 7-92). Gyldendal. (Opprinnelig utgitt 1860)

Bollnow, O. F. (1969). Eksistensfilosofi og pedagogikk (R. Myhre, Overs.). Fabritius.

Buber, M. (1967). feg og $D u$ (H. Wergeland, Overs.). Cappelen.

Cantet, L. (Regissør). (2008). Entre les murs/Klassen [DVD fransk tale, norske tekster 124 min.]. Star Media Entertainment.

Comenius, J. A. (1966). Informatorium for skulen hennar mor (M. Blekastad, Overs.). Universitetsforlaget.

Dardenne, J.-P. \& Dardenne, L. (Regissører). (2011). Le gamin au velo/Gutten med sykkelen [Strømming via Filmarkivet, fransk tale, norske tekster 84 min.]. Star Media Entertainment AS. Tilgjengelig fra https:// www.filmarkivet.no/film/details.aspx?filmid $=11501$

Dennison, G. (1999). The lives of children:The story of the First Street School. Boyton/Cook Publishers. (Opprinnelig utgitt 1969)

Dickens, C. (1935). Hårde tider (H. Rytter, Overs.). Nasjonalforlaget. (Opprinnelig utgitt 1854)

Doucleff, M. (2021). Hunt, gather, parent: What ancient cultures can teach us about raising children. Thorsons Harper Collins Publishers.

Fenstermacher, G. D. (2001). On the concept of manner and its visibility in teaching practice. fournal of Curriculum Studies, 33(6), 639-653. https://doi.org/10.1080/00220270110049886

Gadamer, H.-G. (2010). Sannhet og metode: Grunntrekk $i$ en filosofisk hermeneutikk (L. Holm-Hansen, Overs.). Pax. (Opprinnelig utgitt 1986)

Herdt, J. A. (2008). Putting on virtue: The legacy of the splendid vices. The University of Chicago Press.

Kafka, F. (1991). Brevet til faren (L. Holmboe, Overs.). Cappelen. (Opprinnelig utgitt 1953)

Kant, I. (1803). Immanuel Kant über Pädagogik: Herausgeben bei Friedrich Theodor Rink. Friedrich Nicolovius. https://de.wikisource.org/wiki/\%C3\%9Cber_P\%C3\%A4dagogik

Kierkegaard, S. (2012). Synspunktet for min Forfatter-Virksomhed. I N. J. Cappelørn, J. Garff, J. Kondrup, T. A. Olesen \& S. Tullberg (Red.), Søren Kierkegaards skrifter (bd. 16, s. 5-106). Søren Kierkegaard Forskningscenteret. http://sks.dk/sfv/txt.xml (Opprinnelig utgitt 1859)

Kirkerådet. (2020). Gudstjeneste med veiledninger/Gudsteneste med rettleiingar. Eide forlag.

Kon, S. (regissør). (2003). Tokyo godfathers [DVD engelske tekster 90 min.]. Sony Pictures Entertainment.

Kristjánsson, K. (2016). Flourishing as the aim of education: Towards an extended, 'enchanted' Aristotelian account. Oxford Review of Education, 42(6), 707-720. http://dx.doi.org/10.1080/03054985.2016.1226791

Kristvik, E. (1940). Utfalding og innplanting. Norsk pedagogisk tidsskrift, 24, 294-299 og 309-315.

Løvlie, L. (2021). Politisering og pedagogisk motstand:Veien til en barneorientert praksis. Fagbokforlaget.

Makarenko, A. S. (1977). Pedagogisk poem 1-3. Bd. 1 Veien til livet (N. Fredriksen, Overs.). Ny dag. (Opprinnelig utgitt 1925-1935)

Mehren, S. (1975). Menneske bere ditt bilde frem. Aschehoug.

Murdoch, I. (1970). The sovereignty of good. Routledge \& K. Paul.

Nagibin, J. (1979). Vintereika (K. Saastad, Overs.). I A. Hvenekilde (Red.), Om barn: Antologi og studieopplegg (s. 126-134). Den norske bokklubben. (Opprinnelig utgitt 1953)

NoS. Norsk salmebok 2013. (2013). Eide forlag.

Olin, M. (regissør). (2017). Barndom [DVD norsk tale, norske og engelske tekster 90 min.]. Star Media Entertainment. Tilgjengelig fra https://www.sfanytime.com/no/movie/23841/barndom

Pestalozzi, J. H. (1970). Brevet fra Stanz (E. Fasmer-Dahl, Overs.). I R. Myhre (Red.), Store pedagoger $i$ egne skrifter (bd. 4, s. 54-75). Fabritius. (Opprinnelig utgitt 1799)

Philibert, N. (Regissør). (2002). Etre et avoir/Å vere og ha [DVD fransk tale, norsk tekst $104 \mathrm{~min}$.]. Scanbox Entertainment Norway.

Platon. (2001). Staten (H. Mørland \& T. Frost, Overs.). I Ø. Andersen (Red.), Samlede verker (bd. 5, s. 17-415). Vidarforlagets kulturbibliotek.

Rousseau, J.-J. (2010). Emile, eller Om oppdragelse (K. M. Bessesen, Overs.). Vidarforlaget. (Opprinnelig utgitt 1762)

Sjöberg, C. (1979). Klassens liv (I. Moe, Overs.). Gyldendal. 


\section{S. M. Wivestad}

Sofokles. (441 f. Kr./1964). Antigone (E.Vandvik, Overs.). I Greske tragediar (s. 227-260). Det Norske Samlaget.

Sæverot, H. (2017). Pedagogikkvitenskap. Fagbokforlaget.

Torjussen, L. P. S. (2021). Velskrevet essaysamling med noen gullkorn, men kjapt lest og kjapt glemt. Nordisk tidsskrift for pedagogikk $\mathcal{E}$ kritikk, 7, 36-40. https://doi.org/10.23865/ntpk.v7.2957

Tranøy, K. E. (1960). Vitenskapelig holdning og vitenskap. I A. Aarnes \& E. A. Wyller (Red.), Brytninger $i$ tidens tankeliv (s. 149-158). Tanum.

Tubbs, N. (2005). Chapter 8 Kierkegaard. Fournal of Philosophy of Education, 39(2), 387-409. https://doi. org/10.1111/j.0309-8249.2005.00443.x

Wivestad, S. M. (1993). Tolkning av Jeg og Du. Norsk pedagogisk tidsskrift, 77(2), 106-109. http://www.fagsider. org/sw/artikler/Buber/93Tolkning.pdf

Wivestad, S. M. (1998). Hva er 'vår tradisjon’: Kommentarer og spørsmål til Lars Løvlies artikkel om utdanningsreformens paradokser. Norsk pedagogisk tidsskrift, 82, 286-293.

Wivestad, S. M. (2008). The educational challenges of agape and phronesis. Fournal of Philosophy of Education, 42(2), 307-324. https://doi.org/10.1111/j.1467-9752.2008.00626.x

Wivestad, S. M. (2011). Conditions for 'upbuilding': A reply to Nigel Tubbs' reading of Kierkegaard. Fournal of Philosophy of Education, 45(4), 613-625. https://doi.org/10.1111/j.1467-9752.2011.00823.x

Wivestad, S. M. (2013). Pedagogikkbegrepets historie: Hva bør være programmet for pedagogisk studium og forskning? Norsk pedagogisk tidsskrift, 97(3), 210-222. http:/www.fagsider.org/sw/artikler/Pedagogikkbegrepet 130807-endeligNPT-sidetall.pdf

Wyller, E. A. (1960). Om metodeproblemet i åndsvitenskapene. I A. Aarnes \& E. A. Wyller (Red.), Brytninger $i$ tidens tankeliv (s. 121-148). Tanum.

Aasheim, L. (2015). Hvordan kan dokumentarfilmen Buck inspirere voksne som oppdrar barn og unge og bidra til bedre innsikt? [Masteroppgave]. NLA Høgskolen. 